\title{
Information and Communication Technology Awareness among Teacher Educators
}

\author{
M. J. Philomina and S. Amutha
}

\begin{abstract}
Information and Communication Technology (ICT) has influenced all aspects of life. Processing the knowledge of ICT is really the need of the hour. This paper describes the ICT awareness among teacher educators. The framework raises important questions of how teachers use technological devices in their teaching learning process in order to understand the concept in a better way. It also emphasizes teachers to integrate technology into the instruction in the 21 st century. The aim of the present study is to appraise the awareness among teacher educators in Tiruchirappalli district in India. The sample of the present study consists of 42 teacher educators. Descriptive analysis were used to analyze the data. The results indicate that Indian teacher educators awareness towards ICT differs regarding gender and subject. When compared with M.Ed. and M.Phil. scholars, Ph.D. scholars surpassed the M.Ed. and M.Phil. scholars in terms of ICT awareness in different dimensions. Indeed in India teacher educators' awareness on ICT integration needs to be strengthened.
\end{abstract}

Index Terms-Information and communication technology, ICT awareness, teacher educators, pedagogy.

\section{INTRODUCTION}

Information and Communication Technology (ICT) has suffused in every walks of life influencing the technology fields such as enabling satellites, business, commerce, and also social networking. In this fast-growing and fast-changing digital era, teaching becomes the most challenging profession all over the world, where knowledge is expanding and exploring quickly and much of it is available to students as well as teachers at their learning environment [1]. To meet the educational needs of the Gen $\mathrm{Z}$ society, active learning, critical thinking, problem solving skills, communication skills, information handling skills and self-directed learning are referred as 'twenty-first century skills [2]. [3] Researchers observed an orientation towards twenty-first century learning of teachers in some of the European countries, and a growing orientation in some Asian Countries, when comparing data of 1997 with data of 2006. Their observation shows that changes in national educational policies had an impact on teacher's orientation towards twenty-first century learning.

Policy makers, leaders and researchers need to work together to inculcate the $21^{\text {st }}$ century skills in curricula along with ICT to meet the challenges in teaching and learning in order to achieve learning objective.

Manuscript received December 30, 2014; revised March 4, 2015.

The authors are with the Bharathidasan University of Tiruchirappalli, Tamil Nadu, India (e-mail: srphilomsmi@gmail.com, amuthapraveen@gmail.com).
According to researcher [4] to support and sustain meaningful changes in teaching and learning, teacher education programs should go ahead skills development and implement the following three components: building collaborative structures, modeling effective technology use, and reflecting on current practices and beliefs.

Researcher [5] identified pedagogical content knowledge (PCK) as the knowledge required by teachers to transform content so that it is accessible to learners. The necessary basis for that evolution is both content and pedagogical knowledge, which students will be evolving by the time they register in the ICT pedagogy course. The concept of PCK has been extended [6] to contemplate the interchange with knowledge of technology (ICT) in technological pedagogical content knowledge (TPCK). TPCK is the knowledge that enables teachers to solve the problems of practice by planning appropriate combinations of pedagogy and ICT to support learners working with content in a specific context. Further, they suggest that TPCK is essential "but not sufficient for teachers to become creative or innovative in their thinking about using technology for scholastical needs". Researcher [7] stated that ICT allows teaching and learning activities by educational innovations and by connecting students and teachers to each other and to a vast array of human and informational resources around the world.

Researchers [8] have stated that three important characteristics autonomy, capability, and creativity are needed to develop good quality teaching and learning with ICT skills. As teacher education is primarily directed towards preparing teachers, the quality of education relies on the teacher trainee's capability, creativity and skills. The teacher educators have to accept the demand of the modern world and modify their old concepts and methods according to the needs of the trainees and to provide students with the skill to function effectively in this knowledge explosion era.

\section{LITERATURE REVIEW}

The role of technology in teaching and learning is rapidly becoming one of the most important and widely discussed issues in contemporary education policy. Most experts in the field of education agreed that when rightly practiced, information and communication technology hold great promise to improve teaching and learning. Many studies have found positive effects associated with technology aided instruction. The investigator [9] carried out a survey on pre-service teachers' attitude towards computer use in Singapore. 139 sample pre-service teachers were assessed for their computer attitudes using questionnaire with four factors: affect (liking), perceived usefulness, noticed control, and 
factual intention to use the computer. He stated that teachers were more specific about their attitude towards computers and intention to use computer than their perception of the usefulness of the computer and their control of the computer. Researchers [10] also conducted a study about factors which influence the innovative use of ICT by teacher educators in the Netherlands.120 teacher educators were the sample and the study revealed that student oriented didactical approach, decisive attitude towards computers, clear experience of computers, and personal enterprise of the teacher educators have a direct positive influence on the innovative use of ICT by the teacher.

In a qualitative multiple case-study research on primary school competence and confidence level regarding the use of ICT in teaching practice conducted in five European countries [11] found that technical competence influenced Italian teacher's use of ICT in teaching. In Portugal, teachers reported different views regarding the most important competences for training with ICT. The competent and new teachers emphasized the need for technical skills and attitude, the creative teachers stressed syllabus and instructional competences and the student -teachers cited technical competence and pedagogical efficiency as significant to integrate ICT in teaching and learning process. According to them [11], teachers with more experience with computers have greater confidence in their ability to use them effectively. Investigator [12] reported that teachers' competence relates directly to tenacity. Teachers' tenacity also relate to their understanding of their ability to use computers in the classroom, especially in relation to their children's perceived competence.

Researchers [13], [14] also investigated pre-service teachers' beliefs about the use of computer technology and the effectiveness of ICT programs. The results of these two studies indicate that pre-service teachers recognized the importance of technology integration into their syllabus and believed that ICT use would enhance student learning. They felt that such programs inclined them to apply ICT in the upcoming education scenario, and their capability to evaluate, select, and use a variety of technological devices upgraded. More specifically, [14] they found that ICT courses with direct instruction on the use of technological tools through the technology enhanced lesson (TEL) approach helped teachers to learn how to use technologies as supporting tools in order to enhance their teaching and student learning. Consequently, the pre-service teachers were found to be favorable towards TEL.

Investigator's study [15] showed that there were statistically significant correlations between studying with ICT and the acquisition of critical thinking aptitude. An extensive liability in the ICT environment can encourage students' higher critical thinking aptitude. Thus, schools are strongly advised to inculcate technology across all of the learning areas and among all learning stages. Where, technological applications have been done students are capable of attaining higher levels of technology based cognition within unique learning contexts. The integration of ICT in schools requires external ICT support and professional development policies for teachers and need to have new ICT infrastructure and maintenance [16].
The Ministry of Educational and Vocational Training (MoEVT) in Tanzania has developed the ICT for Teacher Professional Development (ICT-TPD) framework to address the challenges of teacher shortages in key subjects (English, Mathematics and, Science), teacher support, and teacher quality using the existing ICT infrastructure in the Teacher Training Colleges (TTCs) for pre-service, in-service programmmes and ongoing learning of teachers [17]. Using this framework, the Ministry of Educational and Vocational Training of Tanzania also established an ICT for Science, Mathematics and English (ICT-SMEs) project for secondary schools. In consultation with the Ministry of Education and Vocational Training the project was funded by the World Bank and implemented by the Global e-school community Initiatives (GESCI). Teachers from selected schools were trained on the pedagogical use of technology in teaching [18].

Researcher [19] conducted study on "professional competency of teachers and teacher educators in relation to their ICT usage" with the sample of 30 teacher educators and 50 teacher from Government, Government Aided and Aided Minority institution reported that professional competency and ICT usage are significantly related.

According to Investigator [20] teachers should learn not only how to use technology to enhance traditional teaching or increase productivity, but also should learn from a student centered perspective, how ICT can be incorporated into teaching learning process in order to promote student learning. Hence, teachers keep an open mind about ICT integration in the classroom. This means that teachers need to use ICT in more creative and productive ways in order to create more engaging and rewarding activities and more effective lessons [21], [22]. Hence researcher [23] suggested that teachers keep an open mind about ICT integration in classroom. It is crucial that teachers learn new teaching methods to adapt to the new devices when teaching with ICT.

Investigators [24] analyzed pre-service teachers' perspectives regarding ICT in their future classrooms before and after participation in a teacher preparation program. The study revealed that teachers had a better understanding about ICT use in the classroom.

\section{OBJECTIVES}

- To ascertain the ICT awareness among teacher educators.

- To evolve recommendations for policy makers based on the findings.

\section{HYPOTHESIS}

1) Teacher Educators have awareness for ICT integration.

2) There is no significant difference between the arts and science teacher educators towards ICT.

3) There is no significant difference between the awareness of male and female teacher educators towards ICT.

\section{METHOD AND PROCEDURE}

The present study adopted descriptive research with survey technique for data collection. Random sampling method was 
used to collect the data. A questionnaire was developed by the investigator which consists of 20 questions with three point scales, namely 'Yes', 'To some extent', and 'No', and the score is two, one and zero respectively. The questionnaire consists of four dimensions namely teaching, personal, recreational and research for ascertaining their awareness towards ICT integration in education which was administered by the investigator with 8 Ph.D. scholars, 17 M.Phil. scholars and 17 M.Ed. scholars.

\section{RESULT AND DISCUSSION}

\section{Hypothesis: 1}

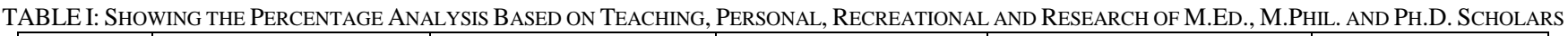

\begin{tabular}{|c|c|c|c|c|c|}
\hline Category & No of Samples & Teach-ing in $\%$ & Personal in \% & Recreational in \% \\
\hline M.Ed. & 17 & 86 & 83 & 80 \\
\hline M.Phil. & 17 & 87 & 78 & 71 \\
\hline Ph.D. & 08 & 91 & 93 & 78 \\
\hline
\end{tabular}

\section{Hypothesis: 2}

From the Table II it is evident that the t-value is 0.09 , which is not significant at 0.05 levels. Thus, the null hypothesis that 'There is no significant difference between the arts and science teacher educators towards ICT' cannot be accepted. Mean ICT awareness score of arts and science teacher educators are 31.5 and 33.68 respectively. It means that as compared to arts teacher educators, science teacher educators have more awareness towards ICT.The study supports the findings of the researcher [25].

TABLE II: MEAN, S.D AND T-VALUE SHOWING THE DIFFERENCE IN THE AWARENESS OF ICT TOWARDS ARTS AND SCIENCE TEACHER EDUCATORS

\begin{tabular}{|l|l|l|l|}
\hline Groups & Mean & SD & ' $t$ 'value \\
\hline Arts & 31.5 & 4.28 & 0.09 \\
\hline Science & 33.68 & 4.31 & \\
\hline
\end{tabular}

\section{Hypothesis: 3}

TABLE III: MEAN, S.D AND T-VALUE SHOWING THE DIFFERENCE IN THE AWARENESS OF ICT TOWARDS TEACHER EDUCATORS BASED ON GENDER

\begin{tabular}{|l|c|c|c|}
\hline Gender & Mean & SD & $\begin{array}{c}\text { ' } t \text { ' } \\
\text { value }\end{array}$ \\
\hline Male & 32.33 & 4.47 & 0.06 \\
\hline Female & 33.04 & 4.42 & \\
\hline
\end{tabular}

From the Table III it is evident that the t-value is 0.06 , which is not significant at 0.05 levels. Thus, the null hypothesis that 'There is no significant difference between the awareness of male and female teacher educators towards ICT' cannot be accepted. Mean ICT awareness scores of male and female teacher educators are 32.33 and 33.04 respectively. It means that when compared with male teacher educators female teacher educators have more awareness towards ICT. Contrary with the findings of the investigators [26].

\section{RECOMMENDATIONS}

Following are the recommendations evolved on the basis of the findings.
From the Table I it is evident that the teacher educators have awareness for ICT integration. The M.Ed. teacher educators' use of ICT in teaching, personal, recreational and research is $86 \%, 83 \%, 80 \%$, and $82 \%$ respectively.

Regarding M.Phil. teacher educators the use of ICT in teaching is $87 \%$, personal $78 \%$, recreational $71 \%$ and in research is $76 \%$.

As far as the Ph.D. teacher educators are concerned the use of ICT in teaching, personal, recreational and research is $91 \%$, $93 \%, 88 \%$ and $78 \%$ respectively. Compared with all samples Ph.D. scholars outperformed the M.Phil. and M.Ed. teacher educators.
1) Teacher educators are to be oriented on ICT integration with national and global expertise.

2) The practicum on ICT integration in teaching and learning may be included in the teacher education curriculum at all levels.

3) Creation of appropriate instructional and infrastructural facilities for ICT integration in all the teacher education institutions is made mandatory.

\section{CONCLUSION}

ICT has undoubtedly become a powerful tool that is breaking the traditional teaching methods of education. ICT incorporated teaching learning process may lead the education system to be more productive and creative. The awareness of ICT is necessary in the 21 st century teacher educators since the conventional modes of teaching learning will not serve the purpose. There is no doubt that ICT based teaching learning process will enhance the outcome of education.

\section{REFERENCES}

[1] B. Somekh, "Understanding the use of interactive whiteboards in primary science," Australasian Journal of Educational Technology, vol. 29 , no. 2 , pp. 217-232, 2013.

[2] K. Kreijns et al., "Adopting the integrative model of behaviour prediction to explain teachers' willingness to use ICT: A perspective for research on teachers' ICT usage in pedagogical practices,' Technology, Pedagogy and Education, vol. 22, 2013.

[3] N. Law et al., "Policy impacts on pedagogical practice and ICT use: An exploration of the results from SITES 2006," Journal of Computer Assisted Learning, vol. 26, pp. 464-477, 2010.

[4] P. A. Ertmer, "Transforming teacher education: Visions and strategies," Educational Technology Research and Development, vol. 51, no. 1, pp. 124-128, 2003.

[5] L. S. Shulman, "Those who understand: Knowledge growth in teaching," Educational Researcher, 1986.

[6] P. Mishra and M. J. Koehler, "Technological pedagogical content knowledge: A framework for teacher knowledge," Teachers College Record, pp. 1017-1054, 2006. 
[7] R. Kozma, "ICT and educational change: A global phenomenon," in R. Kozma, (Ed.), Technology, Innovation and Educational Change: A Global Perspective, pp. 1-19, 2003.

[8] D. L. Lowther et al., "Does technology integration work when key barriers are removed?" Educational Media International, vol. 45, pp. 195-213, 2008

[9] T. Teo, "Pre-service teacher's attitude towards computer use: A Singapore survey," Australian Journal of Educational Technology, vol. 24, no. 4, pp. 413-424, 2008.

[10] M. Drent and M. Meelissen, "User acceptance of information technology: Theories and models," Annual Review of Information Science and Technology, vol. 31, pp. 3-32, 2008.

[11] H. Peralta and F. A. Costa, "Teachers' competence and confidence regarding the use of ICT," Educational Science Journal, vol. 3, pp. $75-84,2007$.

[12] A. Jones, "A review of the research literature on barriers to the uptake of ICT by teachers," British Educational Communications and Technology Agency, 2004.

[13] D. Serhan, "Preparing pre-service teachers for computer technology integration," International Journal of Instructional Media, vol. 36, pp. 439-447, 2009.

[14] C. S. Chai, J. H. L. Koh, and C.-C. Tsai, "Facilitating pre-service teachers' development of technological, pedagogical, and content knowledge (TPACK)," Educational Technology and Society, vol. 13, pp. 63-73, 2010.

[15] G. Mcmahon, "Critical thinking and ICT integration in a Western Australian secondary school," Educational Technology and Society, vol. 12 , pp. 269-281, 2009.

[16] M. O. Egea, "Neoliberalism, education and the integration of ICT in schools," A Critical Reading: Technology, Pedagogy and Education, vol. 23, no. 2, 2014

[17] United Republic of Tanzania. (2009). A frame work for ICT use in teacher professional development in Tanzania. Dares Salaam. [Online]. $19 . \quad$ Available: www.gesci.org/old/files/docman/ICT_TPD_final_Dec_2_09.doc

[18] K. Ayoub and K. Jared, "Teachers' perspectives on their use of ICT in teaching and learning: A case study," Educational and Information Technology, 2014.

[19] J. Kumar et al., "A study on the ICT awareness of M.Ed. trainees," Professional Competency of Teachers and Teacher Educators in Relation to Their ICT Usage, 2007.

[20] E. Tezci, "Factors that influence pre-service teachers' ICT usage in education," European Journal of Teacher Education, vol. 34, pp. 483-499, 2011

[21] A. Birch and V. Irvine, "Pre-service teachers' acceptance of ICT integration in the classroom: Applying the UTAUT model," Educational Media International, vol. 46, pp. 295- 315, 2009.
[22] E. Honan, "Barriers to teachers using digital texts in literacy classrooms," Literacy, vol. 42, pp. 36-43, 2008.

[23] C. Sánchez and E. C. Alemán, "Teachers' opinion survey on the use of ICT tools to support attendance-based teaching," Journal Computers and Education, vol. 56, pp. 911-915, 2011.

[24] A. Doering, J. Hughes, and D. Huffman, "Pre-service teachers: Are we thinking with technology?" Journal of Research on Technology in Education, vol. 35, pp. 342-361, 2003.

[25] U. Pratik, "Students attitude towards computer - A study," International Journal of Creative Research Thoughts, vol. 1, no. 5, pp. 1-4, 2013.

[26] B. M. Madhu, "A study on the ICT awareness of M.Ed. trainees," International Journal of Business Management and Economic Research, vol. 3, no. 4, pp. 573-578, 2012.

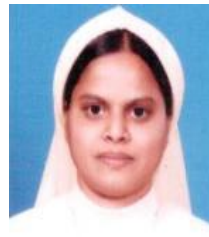

M. J. Philomina was born in Calicut, India in 1977 She is a Ph.D. candidate in the Department of Educational Technology Bharathidasan University, Tiruchirappalli. She received her M.Ed. degree from Osmania University, Hyderabad in 2012. Her research interests include technology, pedagogy and English language teaching. She has been awarded the Best Paper in the International Conference on "Trends and Innovations in Language Teaching", paper entitled "Awareness of primary school teachers in Kerala towards technology -pedagogy integration in ELT at primary level" and she also received the Best Technical Paper Presentation Award in the National Conference on "Innovative Approaches in Teaching and Future Prospects of Educational Technology", paper entitled "Empowering teachers through technology in teacher education."

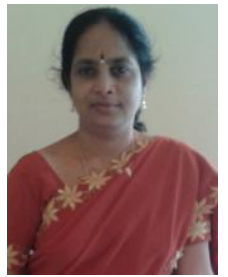

S. Amutha was born in India. She has been working as an assistant professor in the Department of Educational Technology Bharathidasan University, Tiruchirappalli. Her areas of specialization are educational psychology, ICT, e-content development and cognitive science. She has more than 15 international and 14 national publications and 11 edited books. She has been awarded Dr. Aruna Rajagopal Ariviyal Tamil Virudhu given by Anaithindia Ariviyal Tamil kazhagam, Tamil University, Thanjavur, India. She has authored two books - 'Career Education' and 'Philosophy of Education'. She is the life time member of five research journals and one member of other two journals as well. She has 14 years of experience in the field of education. She has been serving as a project fellow for the UGC Major Research Project at the Department of Educational Technology, Bharathidasan University, Tiruchirappalli, India. 